found in the urine. The following question was put by Sir C. Russell to Mr. Paul : "Taking Dr. Humphreys' account of what he did-that he put the urine over the flame of a lamp for two minutes until he brought it to the boiling point, I want to ask you whether, if a serious, a fatal, dose had been administered within, I would say, a fortnight of that time, there must, in your judgment, have been a deposit shown upon the copper?" Answer: "There must, in my judgment." Then, that there might be no mistake about what was meant, Sir Charles added: "I mean taking the test which Dr. Humphreys described that he imperfectly made?" "Yes." Cases bearing upon this point, where the analysis has been made by competent men, should therefore be valuable. The Duc de Praslin took a fatal dose of powdered arsenic on Aug. 18th, and died at 4.35 P.M. on the 24th of the same month. The urine passed in the night of the 21 st contained a little arsenic ; that passed on the 24th, none. The analysts were Chevallier, Orfila, and Tardieu ; and, commenting on the absence of arsenic on the 24th, the two latter remark: "Nous devons dire que ce résultat négatif n'a rien qui doive surprendre. L'un de nous a signalé depuis longtemps ce fait, à savoir: que l'on peut trouver de l'arsenic dans l'urine à telle époque de l'empoisonnement et ne pas en déceler plus tard." The circumstances surrounding the Duc de Praslin's case, and especially the closeness with which it was watched and reported on several times daily, give great value to the recorded facts, and it is remarkable how many resemblances there are between them and those of Mr. Maybrick's illness. The Duke took poison in the afternoon or evening of the 18th. Vomiting commenced about 10 P.M. on the same day. On the 19th, on leaving a bath, there was one involuntary evacuation of the bowels. On the 20 th there was no action, and no pain in the abdomen either with or without pressure, but the extremities were very cold. On the 21 st, at $5 \mathrm{~A}$. M., there was still no abdominal pain, no vomiting or retching, very urgent thirst, and the pulse was 80 to 85 . In the evening the abdomen was distended and a little painful; no vomiting; no stool ; constriction of throat severe. On the 22nd there was neither nausea nor vomiting; there were two stools following enemata; abdomen distended and painful to the touch; burning from throat to anus. In the night fainting occurred, and there was complete insomnia. On the $23 \mathrm{rd}$ the symptoms were intensified; no stools; no urine. On the 24 th death took place at 4.35 P.M. The lateness of the abdominal pain, the late onset and, with the exception of the motion after the bath, very moderate character of the diarrhœa, the absence of cramps and of conjunctivitis, the sleeplessness, the coldness of the extremities, and the long interval between the fatal dose and death, are curiously similar in the two cases. The Duc de Praslin lived six days; Mr. Maybrick eight.

Liverpool.

\section{A CONTRIBUtion TO THE}

\section{MORPHOLOGY OF THE SACCHAROMYCETE OF DIABETIC URINE.}

\section{BY J. BARKER SMITH, L.R.C.P.}

THE case of diabetes which furnished the study of this saccharomycete terminated fatally after a few years, and was that of a young Jewess. The specific gravity of the urine and the percentage of sugar were fairly constant throughout, the former approximating to 1044, the latter to $4 \frac{1}{2}$ per cent. It was the appearance of some fusiform particles in the urine under the microscope, these slightly undulated and with a double contour, that invited an investigation which was continued over two years. I conjectured that they might have passed through the epithelium of the kidneys, ${ }^{I}$ but it was not until I had grown aerial forms that their history became apparent, and that they were recognised as the broken segments of mother cells or spores, which differed, again, from those afterwards grown by me in not losing their double contour by immersion.

Four phases in the morphology of this saccharomycete may be mentioned:-(a) Torula phase: Settling like heavy veast on the bottom of the vessel containing the urine, the aceto-amide reaction with iron increasing; during this period the fungus might be mistaken for a micrococcus or
micrococcous form of bacterium ureæ, \&c. (b) Mould phase: Throwing up hyphe above the surface of the urine or culture solution, the hyph being first white, then yellowish or brown, or, under certain conditions of light and culture, pitchy black. (c) Differential phase: Resting on the bottom of the vessel for several weeks under starved conditions, the vessel containing water only. Both clavate and globular terminal cells may be observed, from which escape smaller round cells without nuclei, but with a few pinkish cells between them. Barrel cells are also present, apparently formed by conjugation. (d) Aspergillus phase: Growing well on moistened bread, forming a dark greenish grey or canescent patch, which becomes bluish olive green when treated with spirit or ether. This phase is interesting because it is an example of one of the facts which enable us to conclude that the physiology of the larger fungi is sonewhat explanatory of that of the smaller. The aspergillus form, for instance, may be traced to a lower or micrococcous form, whilst its extracts exhibit some of the constituents of the larger fungi. This analogy I purpose treating more at length in a future paper; there are numerous interesting developments connected with the simple facts here stated.

The urine evaporated gave a gummy opaque mass, surrounded by crystalline granules of modified uric acid. The ethereal extract recovered by spirit and diluted with water exhibited in a few days hyphæ growing above the solution. A sample of urine acidulated with hydrochloric acid and agitated with ether afforded two layers, the upper one clear and the lower one turbid. The clear layer gave a semi-crystalline extract, containing two organic forms, one subspherical and the other fusiform (débris of mother cells). The turbid layer gave a clear gummy extract, surrounded by crystalline granules and containing three sorts of organic forms, round complete cells, and débris of incomplete cells. The fungus was grown in various solutions, and the cells were found to differ in size according to the culture solution, whilst their shape varied according to position in or out of the culture solution. None of the forms, however, differed so widely as to be indistinguishable. The most constant characters of the aspergillus forms of the fungus are the macroscopic appearance of the patch, the branched hyphre supporting the spores, terminal hyphæ with constrictions supporting two terminal subspherical spores from a well-marked node or constriction (similar to the basidospores with sterigmata of the larger fungi), submoniliform appearance of other terminal hyphæ, and the double contour of the spores themselves, which contour is immediately lost on immersion in fluid. The spores become very small when grown in citric acid solution, remaining distinct, however, from the common aspergillus of lemons, which sometimes resembles a starved mucor. They grow in a 2 per cent. phosphate of ammonia solution with a somewhat larger percentage of citric acid; also in similar salts with glycerine, sugar, \&c.; the mould form eventually becoming yellowish-brown, the brown or even blackish colour not being apparently distinct from the yellow except by quantity or condensation. In this form perhaps only a single central nucleus will be found, the pinkish nucleus becoming clear or of a steely-blue colour on altering the focus, whereas the aspergillus forms often exhibit in their spores two to four nuclei. Bread forms a good culture-bed for these aspergillus forms ; they may be kept six months or longer in a chip-box, the spores retaining their vitality-e.g., examination of spores-after six months. Dry : Cells somewhat smaller than a blood-corpuscle; cell wall dark in colour and well marked, an outer halo and an inner pinkish one under altered focus ; some with hyaline centres; others containing from three to four rose-coloured nuclei ; others, again, with bluish granular contents. Moist: The somewhat oval spores become round; the double contour of the cell wall disappears and becomes evident as a dark line pinkish nuclei become motile and are extruded as spores; cell contents become larger, but remain clear and homogenous.

\section{Supplement to the Paper on the Fungus of DIABETIC URINE.}

In the study of the fungus of diabetes four phases in the life history of the same plant were selected. In studying other fungi than the schizomycetes, we may select these phases as types, leaving, however, the morphological history of the different fungi incomplete, and not confusing the term micrococcous form with micrococcus. 
Torula type.-Examples may be found in the mucus from the evacuations of children suffering from autumnal catarrhal diarrhoa, in which there is a history of cold meat or some article of diet taken twelve hours before. Cells in various stiges of development are found, and may be traced through several phases to the more complete endogenous mother cell, whose walls are breaking away to afford exit to the four complete daughter cells. At this moment the endogenous mother cell somewhat resembles those compact cells of four in a group found in myxoedemic and gonorrhoeic urines, \&c. The micrococcous form of this type is well illustrated by the mucous membranes, or even epidermis, of the gouty and the rheumatic, in their secretions and excretions, or even in the well water contaminated thereby; also by the small pink nuclei from the uvula and fauces, especially before a case of tonsillitis. In a similar way, I am persuaded, may be found in syphilis, recent or remote, those streptococcus germs like small definite specks, under a fifth of an inch, which are supposed to cause it-i.e., not only in the blood about a chancre, but also in the ventricose hair from a patch of syphilitic psoriasis, or, again, in the urine. The urine of gouty and rheumatic patients submitted to cultivation. affords a variety of forms which refuse for months to grow in solutions of urea unless sugar is added, whilst growing freely in solutions of uric acid; some of these are often greenish in colour. With rheumatism and gout in view, some early experiences of mine as a fungus eater more than twelve years ago may be mentioned. I had with a companion partaken of fungus (Coprinus atramentarius) at breakfast every day for a week, when I awoke one morning with pain in my right ilium, and later on in the ankles and soles of the feet, which rendered locomotion painful; my ankleswere weak, and I was nearly crippled; getting well after taking iron and discontinuing the fungus. My companion after a few days experienced the same symptoms. The experiment was again repeated in both cases, with the same result. Moreover, one of my patients had been a sufferer from apparently rheumatic pains in the calves of the legs, and was always benefited by a short course of iron. Finding he was in the habit of eating uncooked mushrooms, I advised him to discontinue his habit; he did so, and lost his pain, which he had had at irregular intervals for years, and he has remained free from them ever since. Another interesting one-celled fungus was found in the bile-stained urine of a jaundiced patient who had pain under the right scapula, and whose symptoms came on after exposure in a damp meadow in autumn. Its distinctive characters were its bright halo, apparently with ciliæ, its motility, and its small oblong pink nucleus. I think I have seen the same fungus emerging from one of the desmids, and in some cases of pneumonia in children.

I shall not attempt to illustrate the mould type, though I suspect some of the forms found in rheumatism and gout would enable me to do so; I will therefore pass on to those resembling aspergillus.

Aspergillus type.--In many cases where there is an aspergillus growing on the ceiling in a corner of a bedroom the inmates will exhibit various forms of irritation referable to the mucous membrane and the skin. Such are conjunctivitis, larynceal irritation, bronchial catarrh, bladder irritability, and itching papules of the skin, often persisting for months, and especially coming on after measles; troubles of the external ear, and even attacks of epilepsy. also ringworm. A microscopical examination from the different parts affected will confirm the analogy with the aspergillus of damp paper, although we may be left with a suspicion, which is strengthened by our study of the diabetic saccharomycete, that we have in the spores of what we pass as those of bacterium ureæ possibly those of an aspergillus living under other circumstances of growth. Certainly I have sought oxalates in the aspergillus hitherto unsuccessfully; they are found in mucor, as a possible cause of the irritations of mucous membranes in such cases, which often resemble the respiratory dyspnoea and bladder irritation associated with oxalates, but I have not proved that the aspergillus contains them in any form. Of this, however, I am assured: that the larger fungi are explanatory of the smaller fungi, in physiology and in chemical constitution-e.g., the constant occurrence of tyrosine-like crystals, easily extracted by spirit, and cramming the spores of the larger fungi, \&c. In poisoning by some of the larger fungi (apart from irritant resins of the russulas or the muscarin of the amanitæ) there is also much to remind one of oxalic acid and cholera. Oxalates do occur in the fungi, not only outside the hyphæ but inside; I attribute the poisonous nature of the puff-ball to this fact as much as to the ripening of the spores, for at the time when this fungus becomes yellow and poisonons, crystals of calcic oxalate crowd the hyphr. Some of these points were men tioned by $m e$ in a letter published in THE LANCET of Aug. 30th, 1884.

An interesting case which has lately come under my care has increased my interest in oxalates, and made me consider another mode of their origin in the body in addition to idiopathic formation and ingress by the alimentary canalviz., by the lungs,-and this, perhaps, not always wholly immediately, but indirectly through the agency of micro. coccous forms. Such an experience is probably unrecorded, as the process known as the platinum process has only lately been in use, and my patient was engaged in working the process as an elegant addition to photographic art. $\mathrm{He}$ complained of a cough which he had had for six months, and spat blood for about two months before. He was anæmic, and complained of general weakness, pain in the $b a c k$, and over the region of the heart. His temper was irritable. Sometimes he was absent in mind or self conscious. He had sensations of heat in his head, slight giddiness, and flushing of cheeks frequently. There was no sweating at night or loss of flesh. Physical examination revealed no signs of phthisis; his heart beat irregularly and feebly, and there was a hæmic murmur. The sputa were loaded with small fungus cells, but contained no bacilli. The urine contained abundant minute crystals of calcic oxalate. He had conjunctivitis, which he had also noticed in his fellow-workers. On visiting his dark chamber, brilliant crystals of potassic oxalate glittered like small diamonds everywhere-on the floor, shelf, and bottles. The potassic oxalate is used in the process in hot saturated solution. It may be mentioned that Nägeli found that no fungus grew in oxalate of ammonia and oxalic acid except on the addition of sugar.

Dulwich.

\section{THE HISTORY AND USE OF AN ASTHETICS IN MIDWIFERY.}

\section{By FRED. W. ALLWRIGHT, M.D., L.R.C.S.I.}

(Concluded from $p .1249$, vol. $i .1889$. )

Chloroform: its mode of administration.-A good remedy will fail in its effects if not properly administered. This truism especially applies to anæsthetics, even in surgical practice, while in obstetrics care and skill are essential to the successful use of them, and out of all proportion to the attention bestowed upon the subject in the text-books. No one can be a good administrator of an agent so powerful as chloroform without a careful study of the chemical, physical, and vital principles concerned. A few of these should be clearly understood. As to the exact nature of the changes which it effects in the cells of the nervous centre it is needless to inquire. It is sufficient to know that the effect is by a direct action upon these cells, according to all authorities, and that the chemical theory of former times, which referred the action to suspended oxygenation of the blood, has been abandoned. Neither is artificial anæsthesia cerebral anæmia, although this state accompanies it. Chloroform belongs to that class of poisons which have an elective action upon the nervous system, selecting certain parts and leaving others alone. A special affinity to the nervous system is shown by the preponderating amount found in it; thus, when the amount in the blood is 1 part, there will be in the brain $3 \cdot 25$ and of chloroform $3 \cdot 92$ parts. The rapidity of the action of chloroform is an important fact. Entering the system through the pulmonary circulation, it passes directly with the blood currents to the nervous centres. In like manner, and with the same rapid actics, une system clears itself, and cessation of administration ensures speedy cessation of effect. The fact enforces attention to the importance of intermittence of the inhalation. Paul Bert found that dogs in a mixture of air and chloroform vapour, which required an hour to produce insensibility, invariably died at the end of seven hours. Intermitting administration could be continued indefinitely 